\title{
Women's pelvic floor muscle strength and urinary and anal incontinence after childbirth: a cross-sectional study*
}

\author{
Força muscular perineal e incontinência urinária e anal em \\ mulheres após o parto: estudo transversal \\ Fuerza muscular perineal e incontinencia urinaria y anal en \\ mujeres después del parto: estudio transversal
}

Priscila Tavares Zizzi ${ }^{1}$, Karina Fernandes Trevisan¹, Nathalie Leister ${ }^{1}$, Camila da Silva Cruz ${ }^{1}$, Maria Luiza Gonzalez Riesco ${ }^{2}$

How to cite this article:

Zizzi PT, Trevisan KF, Leister N, Cruz CS, Riesco MLG. Women's pelvic floor muscle strength and urinary and anal incontinence after childbirth: a crosssectional study. Rev Esc Enferm USP. 2017;51:e03214. DOI: http://dx.doi.org/10.1590/S1980-220X2015039203214

* Extracted from the dissertation "Força muscular perineal e incontinência urinária e anal em mulheres após o parto: estudo transversal", Escola de Enfermagem, Universidade de São Paulo, 2015.

${ }^{1}$ Universidade de São Paulo, Escola de Enfermagem, Programa de Pós-Graduação em Enfermagem, São Paulo, SP, Brazil.

${ }^{2}$ Universidade de São Paulo, Escola de Enfermagem, Departamento de Enfermagem Materno-Infantil e Psiquiátrica, São Paulo, SP, Brazil.

\section{ABSTRACT}

Objective: To analyse pelvic floor muscle strength (PFMS) and urinary and anal incontinence (UI and AI) in the postpartum period. Method: Cross-sectional study carried out with women in their first seven months after childbirth. Data were collected through interviews, perineometry (Peritron ${ }^{\mathrm{TM}}$ ), and the International Consultation on Incontinence Questionnaire-Short Form (ICIQ-SF). Results: 128 women participated in the study. The PFMS mean was $33.1(\mathrm{SD}=16.0) \mathrm{cmH}_{2} \mathrm{O}$ and the prevalence of UI and AI was $7.8 \%$ and $5.5 \%$, respectively. In the multiple analyses, the variables associated with PFMS were type of birth and cohabitation with a partner. Newborn's weight, previous pregnancy, UI during pregnancy, and sexual activity showed an association with UI after childbirth. Only AI prior to pregnancy was associated with AI after childbirth. Conclusion: Vaginal birth predisposes to the reduction of PFMS, and caesarean section had a protective effect to its reduction. The occurrence of UI during pregnancy is a predictor of UI after childbirth, and women with previous pregnancies and newborns with higher weights are more likely to have UI after childbirth. AI prior to pregnancy is the only risk factor for its occurrence after childbirth. Associations between PFMS and cohabitation with a partner, and between UI and sexual activity do not make possible to conclude that these variables are directly associated.

\section{DESCRIPTORS}

Urinary Incontinence; Fecal Incontinence; Postpartum Period; Muscle Strength; Obstetric Nursing. 


\section{INTRODUCTION}

The weight gain during pregnancy and injuries to the pelvic floor tissues caused by birth are often associated with a reduction in pelvic floor muscle strength (PFMS), and might result in pelvic floor dysfunctions such as urinary incontinence (UI) and anal incontinence (AI) ${ }^{(1-2)}$.

UI is defined by the International Continence Society (ICS) as the complaint about involuntary leakage of any amount of urine, and it is classified according to the symptoms presented. The most common types of UI in women are: stress incontinence (leakage of urine during physical effort, cough or sneeze); urge incontinence (leakage of urine preceded by or during urgency to urinate); and mixed incontinence (association of stress UI with mixed UI) ${ }^{(3)}$.

The influence of pregnancy and type of birth on UI has been widely studied, and it is often accepted that parity and vaginal or instrumental birth are associated with this dysfunction. However, there is no evidence showing that caesarean section reduces the risk for UI, especially when is preceded by labour ${ }^{(4-8)}$. In addition to pregnancy and childbirth, the correlation between UI and other factors such as maternal age, weight of the newborn (NB), and previous UI are being researched ${ }^{(6,9-10)}$.

$\mathrm{AI}$ is defined as the complaint of involuntary loss of any amount of faeces or flatus, and may be classified as faecal incontinence (involuntary loss of faeces) and flatus incontinence (involuntary loss of flatulent gases) ${ }^{(3)}$. Studies on risk factors to $\mathrm{AI}$ are still very controversial; however, the literature has been showing its association with maternal age, previous $\mathrm{AI}$ or $\mathrm{AI}$ during pregnancy, instrumental birth, and anal sphincter injury ${ }^{(11-14)}$.

In addition to affecting physical health, UI and AI have repercussions on sexual and psychological health and social life interfering with women's quality of life $\mathrm{e}^{(6,15-16)}$. However, few women seek professional help and receive treatment, despite the availability of methods for improvement and cure of these dysfunctions ${ }^{(17)}$.

Considering the negative interference of $\mathrm{UI}$ and $\mathrm{AI}$ in women's lives and the availability of methods to prevent and treat them, functional assessment of the pelvic floor muscles and assessment of the impact of UI and AI on quality of life should integrate the clinical routine of healthcare services.

Although there is a considerable amount of literature on the theme approached in this study, issues such as factors associated with the development of UI and AI after childbirth and the association of UI and AI with PFMS still need to be clarified. In addition, further studies on UI in the postpartum period are required, because the theme is scarcely investigated in Brazil.

Therefore, the aim of the present study was to analyse PFMS, UI, and AI in the postpartum period.

\section{METHOD}

A cross-sectional study nested in a cohort of women on PFMS, UI, and AI in their first seven months after childbirth was carried out in a healthcare facility of a supplementary health sector company located in the city of Guarulhos, in the state of São Paulo.
The population of this study was 500 women who participated in the cohort "Perineal care during pregnancy and after childbirth: prevention and morbidity associated with perineal muscle strength, sexual activity, and urinary continence" $^{(19)}$, and the inclusion criteria were: age $\geq 18$ years old; body mass index $<35$; completed elementary school education; single gestation; gestational age $<13$ weeks; without previous urogenital surgery or disease that might intervene in PFMS; not opposed to the insertion of the perineometer's probe in the vagina, or the Valsalva manoeuvre for the measurement of PFMS; without difficulty in understanding the Portuguese language or in communication.

The sample of the present study was 128 women who remained in the cohort in the postpartum period. The other women ( $\mathrm{n}=372$ ) were not included due to loss of follow-up or exclusion from the cohort (by clinical-obstetric complications or performance of Valsalva manoeuvre for the measurement of PFMS).

The dependent variables of this study were: PFMS, UI, and $\mathrm{AI}$; and the independent variables were: sociodemographic characteristics (maternal age; self-reported skin colour; education level; occupation; marital status; cohabitation period); obstetric and clinical history (pregnancy, abortion, previous vaginal and caesarean birth; NB with the higher weight; UI and AI prior to pregnancy and during the present pregnancy; overweight or obesity and pelvic floor exercises in the present pregnancy; present childbirth and postpartum: type of birth; perineal trauma; NB's weight, overweight or obesity and pelvic floor exercises; breastfeeding; contraception; sexual activity); and UI's interference in women's lives.

Data collection was carried out from July 24, 2013 to October 30, 2014 by five researchers (three midwives, one nurse and one physiotherapist). A questionnaire prepared for the study was applied through interviews, and the self-applied International Consultation on Incontinence QuestionnaireShort Form (ICIQ-SF) was also used. Women's weight and PFMS were measured. Sociodemographic, clinical, and obstetric data prior to childbirth were extracted from the cohort's database.

Women with a UI complaint in the four weeks prior to the interviews responded to the ICIQ-SF, which consists of three questions regarding frequency, amount, and interference of UI in daily life, with a final score from 0 to 21. A fourth question refers to times when leakage of urine occurs. This brief questionnaire, translated and validated in Brazil $^{(18)}$ was used to assess UI symptoms and their interference in women's lives.

The PFMS measurement was carried out through perineometry, by means of the electronic pressure perineometer Peritron $^{\mathrm{TM}}$ (Canadian brand Laborie), which consists of a portable microprocessor connected to a sensor located in a vaginal silicone probe of $8 \mathrm{~cm}$ in length and $3 \mathrm{~cm}$ in diameter. When pelvic floor muscles contract and pressure the probe, the PFMS is recorded in the microprocessor on a scale from 0.1 to 300 , and the error does not exceed $1 \mathrm{cmH}_{2} \mathrm{O}$.

The perineometry was carried out according to a technique adopted in a previous study ${ }^{(19)}$. During the PFMS 
measurement, the woman: "were in the gynaecological position and were instructed to contract the pelvic floor musculature. The probe was covered with a disposable condom, externally lubricated with water-based gel and introduced $4 \mathrm{~cm}$ to $6 \mathrm{~cm}$ into the vagina. The perineometer was calibrated by inserting the probe into the vagina and inflating it to $100 \mathrm{cmH}_{2} \mathrm{O}$; after that, the gauge was reset to zero, following the manufacturer's recommendations. The women were asked to contract the pelvic floor musculature as hard as they could, sustaining the contraction for 5 seconds. This contraction was repeated three times with an interval of 30 seconds between them. Three PFMS scores were registered, but only the highest one was considered for analysis"(19). All women received a flyer prepared by the research team on pelvic floor exercises and were verbally guided and encouraged to undertake the exercises at home.

Data were entered and stored in Microsoft Excel software and analyses were done with the SPSS 22.0 version software. Descriptive and inferential analyses of the data were carried out. In the inferential analysis of continuous variables (bivariate analysis), Wilcoxon signed-ranked test, Kruskal-Wallis, and Wilcoxon-Mann-Whitney tests, and Pearson's correlation were used. In the analysis of categorical variables (bivariate analysis), Fisher's exact and McNemar's tests were used.

In the multiple analyses, linear regression was used to determine factors associated with the PFMS, and logistic regression was used to determine factors associated with UI and AI. The backward process was adopted in both analyses, with all variables that presented a $\mathrm{p}$-value $\leq 0.20$ in the bivariate analysis.

All tests were carried out in two-tailed manner, accepting the probability of the occurrence of a type 1 error of $5 \%$ $(p=0.05)$ and confidence interval of $95 \%(95 \% \mathrm{CI})$.

The study was approved by the research ethics committee of the School of Nursing of the Universidade de São Paulo under protocol no. 74373, and conducted in accordance with the ethical standards for human research. All women voluntarily agreed to participate in the study and signed an informed consent form.

\section{RESULTS}

Of the 128 women who participated in the study, 86 were evaluated up to two months (60 days) after childbirth, 38 from two up to four months (61 to 120 days) after childbirth, and four from four to seven months (121 to 208 days) after childbirth.

Maternal age ranged from 18 to 42 years, and most women ( $n=107 ; 83.5 \%)$ were aged between 20 and 35 years. More than half $(n=72 ; 56.2 \%)$ self-declared brown skin colour and the majority reported having completed high school education $(n=101 ; 78.9 \%)$, paid work $(n=94 ; 73.5 \%)$, and cohabitation with a partner $(n=111 ; 86.7 \%)$, which in $83.8 \%$ of the cases was for more than one year.

Regarding obstetric and clinical characteristics prior to the present gestation, $61.7 \%(n=79)$ were primigravidae, $10.9 \%(n=14)$ reported previous abortion, $19.5 \%(n=25)$ reported previous vaginal birth, and $15.6 \%(n=20)$ reported previous caesarean section.
Regarding incontinence, $36.7 \%(n=47)$ and $25.8 \%(n=33)$ of the women reported UI and AI prior to pregnancy, respectively. It is worth mentioning that none of the women with AI had incontinence of faeces, only of flatus.

Regarding the present type of birth, most women underwent caesarean section ( $\mathrm{n}=95 ; 75.4 \%)$, and among those with vaginal childbirth ( $\mathrm{n}=31 ; 24.6 \%), 90.3 \%$ underwent episiotomy. In the first six months after childbirth, $79.7 \%(n=102)$ of the women had resumed sexual activity, $73.2 \%(n=93)$ used some contraceptive method, and $91.4 \%(n=117)$ were breastfeeding.

The average weight of the present NB and the average weight of the previous biggest NB were similar $(3225.4 \mathrm{~g}$ and $3211 \mathrm{~g}$, respectively). Regarding nutritional status, half of the women ( $n=64 ; 50 \%)$ were overweight or obese during pregnancy. There was a slight reduction $(n=58 ; 45.7 \%)$ in the number of overweight women in the postpartum period.

During pregnancy, $44.7 \%(n=51)$ practiced pelvic floor exercises at least twice a week. However, in the postpartum period, this proportion reduced to $21.1 \%(n=27)$.

Of the women who had UI after childbirth, all reported having UI prior to pregnancy or during the present pregnancy, as presented in Table 1. Additionally, of the 69 women with previous UI but who were continent after childbirth, 29 (42.0\%) developed UI during pregnancy and 40 (58.0\%) had previous UI. Of these, 33 had the complaint at the beginning of the pregnancy and seven reported that the UI occurred during the previous pregnancy, with remission before this pregnancy. Among the 33 women continent after childbirth who had UI at the beginning of the pregnancy, 19 (57.6\%) regularly carried out pelvic floor exercises (at least twice a week) throughout pregnancy.

Table 1 - Distribution of women with or without UI after childbirth according to UI prior to pregnancy and UI during pregnancy - Guarulhos, São Paulo, Brazil, 2012-2014.

\begin{tabular}{lccccccc}
\hline \multirow{2}{*}{ Variable } & \multicolumn{3}{c}{ Ul after childbirth } & \multicolumn{2}{c}{ Total } \\
\cline { 2 - 5 } & \multicolumn{2}{c}{ Yes } & \multicolumn{2}{c}{ No } & & \\
\cline { 2 - 5 } & $\mathrm{N}$ & $\%$ & $\mathrm{~N}$ & $\%$ & $\mathrm{~N}$ & $\%$ \\
\hline UI only prior to pregnancy & 1 & 0.8 & 15 & 11.7 & 16 & 12.5 \\
UI only during pregnancy & 3 & 2.3 & 29 & 22.7 & 32 & 25.0 \\
$\begin{array}{l}\text { UI prior to pregnancy and during } \\
\text { pregnancy }\end{array}$ & 6 & 4.7 & 25 & 19.5 & 31 & 24.2 \\
$\begin{array}{l}\text { Without UI prior to pregnancy or } \\
\text { during regnancy }\end{array}$ & - & - & 49 & 38.3 & 49 & 38.3 \\
\hline Total & $\mathbf{1 0}$ & $\mathbf{7 . 8}$ & $\mathbf{1 1 8}$ & $\mathbf{9 2 . 2}$ & $\mathbf{1 2 8}$ & $\mathbf{1 0 0}$ \\
\hline
\end{tabular}

Regarding the ICIQ-SF score during pregnancy, the average was $7.6(\mathrm{SD}=4.0)$, with a minimum of 0 and maximum of 18 and, after childbirth, the average was 9.4 $(\mathrm{SD}=6.0)$, with a minimum of 3 and maximum of 18 . The average of the ICIQ-SF score was higher among women who had had vaginal childbirth than among those with caesarean section (13.0; $\mathrm{SD}=6.4$ and 5.8; $\mathrm{SD}=2.6$, respectively).

With regard to AI, of the seven women who had this complaint after childbirth, five had presented AI prior to pregnancy or during their last pregnancy, and two had never had AI, as showed in Table 2. It is worth mentioning that in all cases of AI, the complaint was only about flatus. 
Table 2 - Distribution of women with or without Al after childbirth according to $\mathrm{Al}$ prior to pregnancy and $\mathrm{Al}$ during pregnancy - Guarulhos, São Paulo, Brazil, 2012-2014.

\begin{tabular}{lccccccc}
\hline \multirow{2}{*}{ Variable } & \multicolumn{3}{c}{ Al after childbirth } & \multirow{2}{*}{ Total } \\
\cline { 2 - 5 } & \multicolumn{2}{c}{ Yes } & \multicolumn{2}{c}{ No } & & \\
\cline { 2 - 6 } & $\mathrm{N}$ & $\%$ & $\mathrm{~N}$ & $\%$ & $\mathrm{~N}$ & $\%$ \\
\hline Al only prior to pregnancy & 2 & 1.6 & 15 & 11.7 & 17 & 13.3 \\
Al only during pregnancy & 1 & 0.7 & 9 & 7.0 & 10 & 7.8 \\
$\begin{array}{l}\text { Al prior to pregnancy and during } \\
\text { pregnancy }\end{array}$ & 2 & 1.6 & 14 & 11.0 & 16 & 12.5 \\
$\begin{array}{l}\text { Without Al prior to pregnancy or } \\
\text { during pregnancy }\end{array}$ & 2 & 1.6 & 83 & 64.8 & 85 & 66.4 \\
\hline Total & 7 & 5.5 & $\mathbf{1 2 1}$ & $\mathbf{9 4 . 5}$ & $\mathbf{1 2 8}$ & $\mathbf{1 0 0}$ \\
\hline
\end{tabular}

The PFMS average was $34.3(\mathrm{SD}=18.8) \mathrm{cmH}_{2} \mathrm{O}$ in the last pregnancy, and 5.0 and $102.0 \mathrm{cmH}_{2} \mathrm{O}$ were the lowest and the highest strengths presented, respectively. There was no statistically significant difference $(\mathrm{p}=0.088)$ in pregnancy PFMS values compared with postpartum values.

The bivariate analysis of the PFMS with other variables shows that there was a weak negative correlation with the variables maternal age $(r=-0.013)$, weight of a previous $\mathrm{NB}$ $(\mathrm{r}=-0.223)$, and weight of the present NB $(\mathrm{r}=-0.104)$.

A statistically significant association was found in terms of the variables cohabitation time with the partner $(\mathrm{p}=0.026)$, vaginal delivery in previous pregnancy $(\mathrm{p}=0.030)$, and cesarean delivery in previous pregnancy $(\mathrm{p}=0.009)$. The PFMS was lower among women with more cohabitation time with their partners $(p=0.026)$, with previous vaginal birth $(p=0.030)$, and without caesarean section $(\mathrm{p}=0.009)$. Regarding the present childbirth, the women who underwent caesarean section presented PFMS higher than those who had vaginal birth, with averages of 35.7 and $25.8 \mathrm{cmH}_{2} \mathrm{O}$, respectively $(\mathrm{p}=0.003)$. For the women who had perineal trauma during birth, the PFMS average was 26.6 compared to $35.2 \mathrm{cmH}_{2} \mathrm{O}$ for those who did not have perineal trauma $(\mathrm{p}=0.012)$.

The UI analysis shows that, among incontinent women, the average maternal age was 31.9 years $(\mathrm{SD}=4.4)$, whereas among women without UI, the average was 26.8 years $(\mathrm{SD}=5.3)$. With regard to the weight of the present $\mathrm{NB}$, the average was $3521.0 \mathrm{~g}(\mathrm{SD}=391.2)$ among women with $\mathrm{UI}$ and $3199.9 \mathrm{~g}(\mathrm{SD}=423.8)$ among women without UI.

The prevalence of UI was higher among women with previous pregnancy $(\mathrm{p}=0.007)$, previous vaginal birth $(p=0.004)$, UI prior to pregnancy $(p<0.001)$, UI during pregnancy $(p<0.001)$, and among those who had not resumed sexual activity $(\mathrm{p}=0.029)$.

Regarding AI, the variables that had a statistically significant association were only age $(p=0.012)$ and AI prior to pregnancy $(\mathrm{p}<0.001)$. The AI frequency increased according to age, and $\mathrm{AI}$ prior to pregnancy was a risk factor to AI after birth.

The variables that presented a $p$-value $\leq 0.20$ in the bivariate analysis were included in the initial model of multiple analysis for the dependent variables PFMS, UI, and AI.

In the PFMS multiple analysis (Table 3), the variables included in the initial model were: cohabitation time; previous abortion; previous vaginal birth; previous caesarean; present type of birth; perineal trauma; sexual activity after birth; and AI after birth. In the final model, the variables cohabitation time, previous caesarean section, and present type of birth maintained a statistically significant association. The results showed that women with cohabitation time of less than one year had, on average, $11.61 \mathrm{cmH}_{2} \mathrm{O}$ more PFMS than those who lived with their partners for more than five years. Regarding previous caesarean section, the FMAP was, on average, $10.36 \mathrm{cmH}_{2} \mathrm{O}$ higher among these women, compared with nulliparous or those with previous vaginal birth. Regarding the present type of birth, it was found that the PFMS was, on average, $8.92 \mathrm{cmH}_{2} \mathrm{O}$ lower among women who had vaginal birth.

Table 3 - PFMS multiple analysis of women after childbirth Guarulhos, São Paulo, Brazil, 2012-2014.

\begin{tabular}{lccr}
\hline \multirow{2}{*}{ Variable } & \multicolumn{3}{c}{ Final model* } \\
\cline { 2 - 4 } & Coefficient & $\mathbf{9 5 \%} \mathbf{C l}$ & P-valuet \\
\hline Cohabitation time (years) & & & \\
$<1$ & 11.61 & 2.29 to 20.92 & 0.015 \\
$1+5$ & 1.42 & -5.74 to 8.58 & \\
$>5$ & 0 & & 0.023 \\
\hline Previous caesarean section & & & \\
Yes & 10.36 & 1.45 to 19.26 & \\
No & 0 & & 0.025 \\
\hline Present type of birth & & & \\
Vaginal birth & -8.92 & -16.71 to -1.14 & \\
Caesarean section & 0 & & \\
\hline
\end{tabular}

*Linear regression; †Student's t-test.

The variables included in the initial model of the UI analysis were: maternal age; weight of the present NB; previous pregnancy; previous abortion; previous vaginal birth; UI prior to pregnancy; AI prior to pregnancy; UI during pregnancy; present type of birth; and sexual activity after childbirth. In the final model, only the variables weight of the present NB, previous pregnancy, UI during pregnancy, and sexual activity after childbirth retained a statistically significant association. However, considering that the test power was low (5\%) for the NB's weight, we can say that the association was random. The probability of having UI after childbirth increased by 13 times among women with previous pregnancy and 20 times among those who had UI during pregnancy. Among women with sexual activity after childbirth, the probability of having UI is $94 \%$ lower (Table 4).

Table 4 - Initial and final models of the multiple analysis of women with UI after childbirth - Guarulhos, São Paulo, Brazil, 2012-2014.

\begin{tabular}{lccc}
\hline \multirow{2}{*}{ Variable } & \multicolumn{3}{c}{ Final model* } \\
\cline { 2 - 4 } & OR & $\mathbf{9 5 \% ~ C l}$ & P-valuet \\
\hline $\begin{array}{l}\text { Weight of the present NB (per } \\
\mathbf{1 0 g} \text { ) }\end{array}$ & 1.03 & $1.0006-1.0518$ & 0.045 \\
\hline $\begin{array}{l}\text { Previous pregnancy } \\
\text { Yes }\end{array}$ & 13.14 & $1.63-106.27$ & 0.016 \\
No & 1 & & \\
\hline
\end{tabular}

continued... 


\begin{tabular}{lccc}
\hline \multirow{2}{*}{ Variable } & \multicolumn{3}{c}{ Final model* } \\
\cline { 2 - 4 } & OR & $\mathbf{9 5 \%} \mathbf{C l}$ & P-valuet \\
\hline UI during pregnancy & & & \\
Yes & 20.43 & $1.70-244.98$ & 0.017 \\
No & 1 & & \\
\hline Sexual activity after childbirth & & & \\
Yes & 0.06 & $0.01-0.49$ & 0.008 \\
No & 1 & & \\
\hline
\end{tabular}

*Logistic regression; †Wald test.

For the multiple analysis of AI after childbirth, the variables maternal age and educational level, although showing a statistical association, were not included due to the existence of categories with a frequency equal to 0 . The variable weight of a previous $\mathrm{NB}$ was not included because the number of cases was much lower than the other variables. Therefore, the variables AI prior to pregnancy, AI during pregnancy, and contraception after childbirth were included in the initial model. In the final model, only AI prior to pregnancy retained a statistically significant association $(\mathrm{p}=0.041)$, showing that $\mathrm{AI}$ prior to pregnancy increases by six times the probability of women to have AI after childbirth $(\mathrm{OR}=6.26$; 95\% CI 1.08-36.43).

\section{DISCUSSION}

Studies on the assessment of PFMS in the pregnancypuerperal period are quite heterogeneous regarding population profile, assessment tools, and time when pelvic floor strength was measured. Therefore, it is not possible to compare the results of PFMS during pregnancy with those from after childbirth. However, there seems to be a consensus that, after childbirth, there is a reduction in PFMS values ${ }^{(1-2)}$.

In the current study, the reduction in PFMS after childbirth in relation to pregnancy was not statistically significant. This finding is in agreement with a cohort study that used the same PFMS assessment method. The authors concluded that pregnancy and childbirth do not significantly change $\mathrm{PFMS}^{(20)}$.

The association between PFMS and type of birth is often approached in the literature, and several studies show that PFMS is lower in women with vaginal birth ${ }^{(2,21-22)}$. After multiple analyses, this association was also observed in the population of the current study, with a higher average of PFMS among women with caesarean section and a lower average among those with vaginal birth. Contradictorily, two recent studies did not find statistically significant differences between PFMS and type of birth ${ }^{(20,23)}$.

An important data of the present study is that most women with vaginal birth had episiotomy. This indicates that the lower PFMS among women with vaginal birth in relation to women with caesarean section might have been influenced by the pelvic floor injury caused by perineal trauma.

PFMS was also inversely proportional to the cohabitation time with the partner. This association was maintained in the multiple analyses, showing that among women who lived with their partners for less than one year, the PFM was $11.61 \mathrm{cmH}_{2} \mathrm{O}$ higher than among women who lived with their partners for more than five years. However, this data must be carefully analysed, because there may be confounding variables associated with it, such as a higher maternal age in women who live with their partners for a longer time.

Prevalence rates of UI after childbirth found in the literature range from $3 \%$ to $40 \%{ }^{(24)}$. This broad range may be partly explained by methodological differences among populations studied and clinical and obstetric characteristics of the studies' samples. The prevalence of UI among women in this study $(7.8 \%)$ is similar to that found in a prospective study in which $6.78 \%$ of puerperal women reported $\mathrm{UI}^{(5)}$.

UI during pregnancy was a determining factor for UI after childbirth, as also shown in other studies ${ }^{(6,25)}$. All women who presented UI after childbirth reported having previous UI before or during pregnancy. The probability of having UI after childbirth increased by 20 times among women who had UI during pregnancy.

It is worth mentioning the high percentage of women with previous UI who became continent after childbirth. The literature emphasizes UI's transitory character, not only in the postpartum period, but also in any period of women's lives. Pregnancy and childbirth, as well as overweight and obesity, are pointed out as occasional risk factors ${ }^{(26-27)}$.

Therefore, these are factors that may explain UI remission in women with previous UI. In addition, more than half of the women in the current study practiced pelvic floor exercises, which might also have contributed to the improvement of UI symptoms.

Another factor that should be considered is the perception of UI as a problem and the possible recall bias when the complaint was informed. Therefore, the ICIQ-SF reports the $\mathrm{UI}$ in the last four weeks, indicating the possible temporariness of the symptom.

Regarding pregnancy and childbirth, there is considerable literature on the association between these variables and UI. There seems to be a consensus that pregnancy is an important risk factor for $\mathrm{UI}^{(5,7,28)}$. With regard to the type of childbirth, several studies found an increased risk for UI in women who had vaginal delivery ${ }^{(6-8)}$; however, further studies monitoring possible confounding factors are required because, based on the available literature, it cannot be concluded that caesarean section has a protective effect on $\mathrm{UI}^{(4)}$. In the current study, the UI frequency was higher among women who had a previous pregnancy and among those with previous vaginal delivery; however, with regard to the present childbirth, a statistically significant difference was not found between type of childbirth and UI. It is likely that the fact that all women who reported UI after childbirth have presented UI previously or during pregnancy has influenced this result. This assumption is strengthened when it is observed that the average of the ICIQ-SF score was higher among women with caesarean delivery compared with the average of women with vaginal delivery.

According to the ICIQ-SF score, the interference of UI in women's lives may be classified as: mild (1-5); moderate $(6-12)$; severe (13-18); and very severe $(19-21)^{(29)}$. In the 
present study, this interference may be considered moderate. When comparing types of childbirth, the interference was considered mild for women with caesarean delivery and severe for those with vaginal delivery. Opposing these results, a longitudinal prospective study ${ }^{(8)}$ showed that, although the prevalence of UI one year after childbirth was higher in women with vaginal delivery, the interference in daily life was not associated with type of childbirth during the six postpartum weeks.

Another variable that maintained an association with UI was sexual activity after childbirth. It was observed that the probability of UI after childbirth was $94 \%$ lower in women who engaged in sexual activity. Studies assessing the association between these variables were not found; however, based on discomfort and negative feelings associated with $\mathrm{UI}^{(16)}$, it is assumed that women with UI avoid sexual activity and not that this performs a protective role against UI.

The literature on AI is scarcer compared with UI, especially in the postpartum period. Although the prevalence and incidence of this dysfunction are unknown, it is known that it is less frequent than $\mathrm{UI}^{(30)}$. In the present study, the prevalence of $\mathrm{AI}$ was $5.5 \%$. Of the seven women with $\mathrm{AI}$ after childbirth, only two did not have previous AI before or during pregnancy.

Similarly to UI, women with previous AI experienced remission of symptoms. This may be considered a finding of the study, because there are no data in the literature on the temporary nature of AI symptoms, both with loss of faeces and flatus, not associated with serious perineal trauma.

The causes of AI after childbirth are not well defined. In addition to the fact that there are few studies approaching this subject, there is a range of different risk factors found among them. In accordance with previous studies ${ }^{(12-13)}$, the results of the present study showed that the probability of $\mathrm{AI}$ after childbirth increased according to maternal age, $\mathrm{AI}$ prior to pregnancy, and AI during pregnancy; however, in the multiple analysis, only AI prior to pregnancy maintained a statistically significant association, increasing the probability of AI after childbirth by six times.

It is worth mentioning that instrumental birth and anal sphincter damage are the risk factors most often found in the literature for AI after childbirth, in spite of controver$\operatorname{sies}^{(11,13-14)}$. In the present study, these variables could not be analysed, since there was no instrumental birth and the degree of perineal trauma was not questioned.
Regarding the limitations of the present study, it can be considered that the limitations often observed in cross-sectional studies were minimized through monitoring the main biases - selection, information, and confusion ${ }^{(31)}$ - described in the Method. In addition, although the sample of this study was a convenience sample (based on the sample calculated for cohort), the test power calculated for the variables that presented a statistically significant association with the PFMS, UI, and AI in the multiple analysis was higher than $98.8 \%$ for all variables, except for the variable weight of the present NB; therefore, the sample size was appropriate for the analysis carried out.

Finally, the results of the present study bring contributions to the knowledge on PFMS, UI, and AI after childbirth, because the clinical and obstetric data analysed were directly obtained during pregnancy and in the first seven months after childbirth. The results confirm the importance of the long-term follow-up of women after childbirth, as also showed in the literature, because the repercussions of pregnancies and childbirth in UI and AI, as well as the temporary and reversible nature of these symptoms, need to be more appropriately established.

For the care practice, the present study may contribute to the knowledge of professionals who work in women's health, thus encouraging an approach to this subject during the prenatal period. At an appropriate time, identifying women with a risk for UI or AI or women who are already incontinent may contribute to the prevention and treatment of these dysfunctions.

\section{CONCLUSION}

PFMS is directly associated with the type of birth, since women who had vaginal births on previous pregnancies or on the present pregnancy studied had incidences of PFMS lower than those who had caesarean section.

UI during pregnancy is a predictor of UI after childbirth. In addition, women with a previous pregnancy have a higher probability of having UI after childbirth, and the interference in women's lives is moderate.

$\mathrm{AI}$ prior to pregnancy is the only risk factor for its occurrence after childbirth.

Associations between PFMS and cohabitation with a partner, and between UI and sexual activity, as shown in this study, do not enable us to conclude that these variables are directly associated.

\section{RESUMO}

Objetivo: Analisar a força dos músculos do assoalho pélvico e a incontinência urinária e anal no período pós-parto. Método: Estudo transversal realizado com mulheres nos primeiros 7 meses após o parto. Os dados foram coletados por meio de entrevista, da perineometria (Peritron $^{\mathrm{TM}}$ ) e do International Consultation on Incontinence Questionnaire-Short Form (ICIQ-SF). Resultados: Participaram do estudo 128 mulheres. A média da força dos músculos do assoalho pélvico foi 33,1 (d.p.=16,0) $\mathrm{cm}_{2} \mathrm{O}$ e a prevalência de incontinência urinária e incontinência anal foi de 7,8\% e 5,5\%, respectivamente. Na análise múltipla, as variáveis associadas à força dos músculos do assoalho pélvico foram tipo de parto atual e coabitação com o parceiro. Peso do recém-nascido, gestação anterior, incontinência urinária na gestação e atividade sexual mostraram associação. Apenas a incontinência anal prévia à gestação associou-se à incontinência anal após o parto. Conclusão: $\mathrm{O}$ parto vaginal predispõe à redução da força dos músculos do assoalho pélvico, e a cesariana exerce função protetora à sua redução. A ocorrência de incontinência urinária na gestação é preditora da incontinência urinária após o parto, e as mulheres com gestação anterior e recém-nascido de maior peso têm maior propensão em apresentar incontinência urinária após o parto. Incontinência anal prévia à gestação é o único fator de risco para sua ocorrência após o parto. As associações entre força dos músculos do assoalho 
pélvico e coabitação com o parceiro e entre incontinência urinária e atividade sexual não permitem concluir que essas variáveis estejam diretamente relacionadas.

\section{DESCRITORES}

Incontinência Urinária; Incontinência Fecal; Período Pós-Parto; Força Muscular; Enfermagem Obstétrica.

\section{RESUMEN}

Objetivo: Analizar la fuerza de los músculos del suelo pélvico y la incontinencia urinaria y anal en el período post parto. Método: Estudio transversal realizado con mujeres los primeros siete meses después del parto. Los datos fueron recolectados por medio de entrevista, de la perineometría (Peritron ${ }^{\mathrm{TM}}$ ) y del International Consultation on Incontinence Questionnaire-Short Form (ICIQ-SF). Resultados:Participaron en el estudio 128 mujeres. El promedio de la fuerza de los músculos del suelo pélvico fue 33,1 (d.p.=16,0) $\mathrm{cmH}_{2} \mathrm{O}$ y la prevalencia de incontinencia urinaria e incontinencia anal fue del 7,8\%, respectivamente. En el análisis múltiple, las variables asociadas con la fuerza de los músculos del suelo pélvico fueron el tipo de parto actual y la cohabitación con la pareja. Peso del recién nacido, gestación anterior, incontinencia urinaria en la gestación y actividad sexual mostraron asociación. Solo la incontinencia anal previa a la gestación se asoció con la incontinencia anal después del parto. Conclusión: El parto vaginal predispone la reducción de la fuerza de los músculos del suelo pélvico, y la cesárea ejerce función protectora a su reducción. La ocurrencia de incontinencia urinaria en la gestación es predictora de la incontinencia urinaria después del parto, y las mujeres con gestación anterior y recién nacido de mayor peso tienen mayor propensión a presentar incontinencia urinaria tras el parto. Incontinencia anal previa a la gestación es el único factor de riesgo para su ocurrencia después del parto. Las asociaciones entre fuerza de los músculos del suelo pélvico y cohabitación con la pareja y entre incontinencia urinaria y actividad sexual no permiten concluir que dichas variables estén directamente relacionadas.

\section{DESCRIPTORES}

Incontinencia Urinaria; Incontinencia Fecal; Periodo Posparto; Fuerza Muscular; Enfermería Obstétrica.

\section{REFERENCES}

1. Friedman S, Blomquist JL, Nugent JM, McDermott KC, Muñoz A, Handa VL. Pelvic muscle strength after childbirth. Obstet Gynecol. 2012;120(5):1021-8.

2. Hilde G, Stær-Jensen J, Siafarikas F, Engh ME, Brækken IH, Bø K. Impact of childbirth and mode of delivery on vaginal resting pressure and on pelvic floor muscle strength and endurance. Am J Obstet Gynecol. 2013;208(1):50.e1-7.

3. Abrams P, Andersson KE, Birder L, Brubaker L, Cardozo L, Chapple C, et al. Fourth International Consultation on Incontinence Recommendations of the International Scientific Committee: evaluation and treatment of urinary incontinence, pelvic organ prolapse, and fecal incontinence. Neurourol Urodyn. 2010;29(1):213-40.

4. Press JZ, Klein MC, Kaczorowski J, Liston RM, von Dadelszen P. Does cesarean section reduce postpartum urinary incontinence? A systematic review. Birth. 2007;34(3):228-37.

5. Valeton CT, Amaral VF. Evaluation of urinary incontinence in pregnancy and postpartum in Curitiba Mothers Program: a prospective study. Int Urogynecol J. 2011;22(7):813-18.

6. Torrisi G, Mininib G, Bernasconi F, Perrone A, Trezza G, Guardabasso V, et al. A prospective study of pelvic floor dysfunctions related to delivery. Eur J Obstet Gynecol Reprod Biol. 2012;160(1):110-5.

7. Oliveira C, Seleme M, Cansi PF, Consentino RF, Kumakura FY, Moreira GA, et al. Urinary incontinence in pregnant women and its relation with socio-demographic variables and quality of life. Rev Assoc Med Bras. 2013;59(5):460-6.

8. Chang SR, Chen $\mathrm{KH}$, Lin HH, Lin MI, Chang TC, Lin WA. Association of mode of delivery with urinary incontinence and changes in urinary incontinence over the first year postpartum. Obstet Gynecol. 2014;123(3):568-77.

9. Glazener CM, Herbison GP, MacArthur C, Lancashire R, McGee MA, Grant AM, et al. New postnatal urinary incontinence: obstetric and other risk factors in primiparae. BJOG. 2006;113(2):208-17.

10. Baracho SM, Silva LB, Baracho E, Filho ALS, Sampaio RF, Figueiredo EM. Pelvic floor muscle strength predicts stress urinary incontinence in primiparous women after vaginal delivery. Int Urogynecol J. 2012;23(7):899-906.

11. Bols EM, Hendriks EJ, Berghmans BC, Baeten CG, Nijhuis JG, Bie RA. A systematic review of etiological factors for postpartum fecal incontinece. Acta Obstet Gynecol Scand. 2010;89(3):302-14.

12. Solans-Domènech M, Sánchez E, Espuña-Pons M; Pelvic Floor Research Group (Grup de Recerca del Sòl Pelvià: GRESP). Urinary and anal incontinence during pregnancy and postparum: incidence, severity, and risk factors. Obstet Gynecol. 2010;115(3):618-28.

13. Brown SJ, Gartland D, Donath S, MacArthur C. Fecal incontinence during the first 12 months postpartum: complex causal pathways and implications for clinical practice. Obstet Gynecol. 2012;119(2 Pt 1):240-9.

14. Malek-Mellouli M, Assen S, Bem Amara F, Gada H, Masmoudi K, Reziga H. Incidence and risk factors of postpartum anal incontinence: a prospective study of 503 cases. Tunis Med. 2014;92(2):159-63.

15. Laine K, Skjeldestad FE, Sanda B, Horne H, Spydslaug A, Staff AC. Prevalence and risk factors for anal incontinence after obstetric anal sphincter rupture. Acta Obstet Gynecol Scand. 2011;90(4):319-24.

16. Leroy LS, Lopes MHBML. Urinary incontinence in the puerperium and its impact on the health-related quality of life. Rev Latino Am Enfermagem. 2012;20(2):346-53.

17. Brown S, Gartland D, Perlen S, McDonald E, MacArthur C. Consultation about urinary and fecal incontinence in the year after childbirth: a cohort study. BJOG. 2014;122(7):954-62. 
18. Tamanini JTN, Dambros M, D'Ancora CAL, Palma PC, Rodrigues Netto Jr N. Validação para o português do "International Consultation on Incontinence Questionnaire-Short Form" (ICIQ-SF). Rev Saúde Pública. 2004;38(3):438-44.

19. Riesco MLG, Trevisan KF, Leister N, Cruz CS, Caroci AS, Zanetti MRD. Urinary incontinence related to perineal muscle strength in the first trimester of pregnancy: cross-sectional study. Rev Esc Enferm USP. 2014;48(n.spe):32-8.

20. Caroci AS, Riesco MLG, Souza WS, Cotrim AC, Sena EM, Rocha NL, et al. Analysis of pelvic floor musculature function during pregnancy and postpartum: a cohort study: (a prospective cohort study to assess the PFMS by perineometry and digital vaginal palpation during pregnancy and following vaginal or caesarean childbirth). J Clin Nurs. 2010;19(17-18):2424-33.

21. Batista EM, Conde DM, Do Amaral WN, Martinez EZ. Comparison of pelvic floor muscle strength between women undergoing vaginal delivery, cesarean section, and nulliparae using a perineometer and digital palpation. Gynecol Endocrinol. 2011;27(11):910-4.

22. Sigurdardottir T, Steingrimsdottir T, Arnason A, Bø K. Pelvic floor muscle function before and after first childbirth. Int Urogynecol J. 2011;22(12):1497-503.

23. Koc O, Duran B, Ozdemirci S, Bakar Y, Ozengin N. Is cesarean section a real panacea to prevent pelvic organ disorders? Int Urogynecol J. 2011;22(9):1135-41.

24. Thom DH, Rortveit G. Prevalence of postpartum urinary incontinence: a systematic review. Acta Obstet Gynecol Scand. 2010;89(12):1511-22.

25. Diez-Itza I, Arrue M, Ibañez L, Murgiondo A, Paredes J, Sarasqueta C. Factors involved in stress urinary incontinence 1 year after first delivery. Int Urogynecol J. 2010;21(4):439-45.

26. Cerruto MA, D’Elia C, Aloisi A, Abrello M, Artibani W. Prevalence, incidence and obstetric factors impact on female urinary incontinence in Europe: a systematic review. Urol Int. 2013;90(1):1-9.

27. Fritel X, Ringa V, Quiboeuf E, Fauconnier A. Female urinary incontinence, from pregnancy to menopause: a review of epidemiological and pathophysiological findings. Acta Obstet Gynecol Scand. 2012;91(8):901-10.

28. Scarpa KP, Herrmann V, Palma PCR, Ricetto CLZ, Morais S. Sintomas do trato urinário inferior três anos após o parto: estudo prospectivo. Rev Bras Ginecol Obstet. 2008;30(7):355-9.

29. Kloving A, Avery K, Sandvik H, Hunskaar S. Comparion of two questionnaires for assessing the severity of urinary incontinence: the ICIQUI SF versus the Incontinence Severity Index. Neurol Urodyn. 2009;28(5):411-5.

30. Hay-Smith J, Mørkved S, Fairbrother KA, Herbison GP. Pelvic floor muscle training for prevention and treatment of urinary and faecal incontinence in antenatal and postnatal women. Cochrane Database Syst Rev. 2008;8(4):CD007471.

31. Medronho RA, Bloch KV, Luiz RR, Werneck GL, editores. Epidemiologia. $2^{\text {a }}$ ed. São Paulo: Atheneu; 2009. 